\title{
$\boldsymbol{J} \mathbf{I P E R}$ \\ FISIP UMMAT | ISSN 2716-0432
}

Vol. 2, No. 2 November 2020, Hal. 88-103

\section{EKSISTENSI PERAN UPT PERPUSTAKAAN UNIVERSITAS MUHAMMADIYAH MATATARAM DALAM MENGHADAPI ERA PANDEMI COVID-19}

\section{Lubis $^{1}$, Iskandar ${ }^{2}$, Widiastuti Furbani ${ }^{3}$}

${ }^{1}$ Prodi DIII Perpustakaan, Universitas Muhammadiyah Mataram

${ }^{2}$ Prodi DIII Perpustakaan, Universitas Muhammadiyah Mataram

${ }^{3}$ Prodi DIII Perpustakaan, Universitas Muhammadiyah Mataram

${ }^{1}$ lubis.vharoso@gmail.com

2iskandarngali94@gmail.com

INFO ARTIKEL

Riwayat Artikel:

Diterima: 25-10-2020

Disetujui: 12-11-2020

\section{Kata Kunci:}

1. Eksistensi

Perpustakaan

2. Covid-19

\section{ABSTRAK}

Perpustakaan perguruan tinggi merupakan perpustakaan yang melayani para mahasiswa, dosen, dan karyawan suatu perguruan tingggi tertentu (akademik, universitas, institut, sekolah tinggi, politeknik). Koleksi suatu perpustakaan perguruan tinggi tidak hanya sebatas pada buku-buku teks yang diperlukan untuk menunjang kegiatan belajar mengajar saja, tetapi juga buku-buku dan jurnal-jurnal ilmiah yang diperlukan untuk menunjang penelitian para dosen dan mahasiswa.

Menurut Sulistyo Basuki (1991), setiap perpustakaan dapat mempertahankan eksistensinya apabila dapat menjalankan pernannya. Secara umum peran-peran yang dapat dilakukan adalah, Sebagai pusat informasi, Sebagai pusat inovasi, Sebagai pusat sumber belajar. Ditengah kondisi Covid-19 saat ini perpustakaan tetap eksis dalam memberikan pelayanan informasi dengan cara menerapkan protokoler kesehatan secara ketat.

\section{A. PENDAHULUAN}

\section{Latar Belakang}

Perpustakaan adalah institusi pengelola koleksi karya tulis, karya cetak, dan atau karya rekam secara profesional dengan sistem yang baku guna memenuhi kebutuhan pendidikan, penelitian, pelestarian, informasi dan rekreasi para pemustaka (Undang-undang RI. No. 43 Tahun 2007 tentang Perpustakaan). Hal ini sesuai dengan peran yang dilakukan perpustakaan yaitu sebagai lembaga yang mempunyai peran penting untuk mengembangkan minat baca dan budaya baca masyarakat, sebagai sumber informasi, pendidikan, penelitian, sebagai media yang menghubungkan antara sumber informasi dan ilmu pengetahuan yang terkandung didalam koleksi perpustakaan, dan perpustakaan sebagai agen perubahan dan agen kebudayaan umat manusia (Sutarno, 2006:68-69).

Undang-undang No. 43 Tahun 2007 Pasal 12 Ayat 1 yang merupakan keputusan pemerintah tentang koleksi perpustakaan menegaskan bahwa "Koleksi perpustakaan diseleksi, diolah, disimpan, dilayankan, dan dikembangkan sesuai dengan kepentingan 


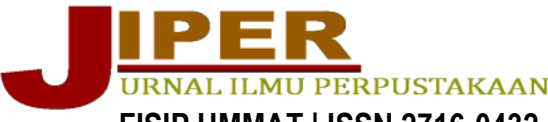

FISIP UMMAT | ISSN 2716-0432

Vol. 2, No. 2 November 2020, Hal. 88-103

pemustaka dengan memperhatikan perkembangan teknologi informasi dan komunikasi”. Perpustakaan sendiri sebagai salah satu bagian dari tempat pendidikan mempunyai peran yang sangat penting untuk menambah wawasan dan pengetahuan mahasiswa. Di perpustakaan terdapat berbagai macam sumber informasi ilmiah, literatur-literatur, serta buku-buku. Mahasiswa seharusnya mampu memanfaatkan perpustakaan sebaik mungkin dikarenakan ilmu pengetahuan dan teknologi belakangan ini terus-menerus berkembang dengan pesat. Perpustakaan yang baik adalah perpustakaan yang memberikan kemudahan bagi pengguna dalam mendapatkan informasi dan bahan pustaka yang diinginkan.

Perguruan tinggi adalah organisasi satuan pendidikan yang menyelenggarakan pendidikan dijenjang pendidikan tinggi, penelitian dan pengabdian kepada masyarakat (Peraturan Pemerintah Nomor 30 tahun 1990). Berdasarkan Undangundang Nomor 2 Tahun 1989 tentang Sistem Pendidikan Nasional pada pasal 55: menjelaskan bahwa salah satu syarat menyelenggarakan perguruan tinggi harus memiliki perpustakaan. Selain itu, untuk mendukung proses belajar agar dapat berjalan dengan baik dan optimal, perlu adanya dukungan dari sumber belajar, alat- alat peraga, bahan-bahan belajar, pengajar lingkungan, metode dan lain sebagainya yang bisa disediakan perpustakaan.

Berdasarkan paparan di atas, peneliti tertarik untuk membahas mengenai bagaimana peran perpustakaan dalam menghadapi era sekarang ini. Maka dari itu peneliti memilih judul "Peran UPT Perpustakaan Universitas Muhammadiyah Matataram dalam menghadapi era new normal".

\section{Tujuan Penelitian}

a. Tujuan Umum

Penelitian ini secara umum bertujuan untuk mengetahui bagaimana Eksistensi Peran UPT Perpustakaan Universitas Muhammadiyah Matataram Dalam Menghadapi Era Pandemi Covid19.

\section{B. METODE PENELITIAN}

Metode yang digunakan dalam penelitian ini adalah metode deskriptif kualitatif, karena tujuannya adalah untuk mendeskripsikan dan menggambarkan apa adanya Eksistensi Peran UPT Perpustakaan Universitas Muhammadiyah Matataram Dalam Menghadapi Era Pandemi Covid-19.

\section{Teknik Pengumpulan Data}

$$
\text { Sugiyono (2013:224) teknik }
$$

pengumpulan data merupakan langkah yang paling strategis dalam penelitian, karena 
tujuan utama dari penelitian adalah mengumpulkan data.

Adapun teknik pengumpulan data yang digunakan oleh penelitiantara lain:

a. Observasi

Nasution (dalam Sugiyono 2013:226) menyatakan bahwa, obsevasi adalah dasar semua ilmu pengetahuan. Metode ini digunakan untuk memperoleh data secara nyata dan mengamati secara lansung peran dan fungsi komunikasi pustakawan dalam peningkatan layanan infomasi di UPT. Perpustakaan Universitas Mataram, peneliti mengamati subyek saat berada perpustakaan, dan saat berada di luar perpustakaan dengan menggunakan pedoman observasi yang telah dipersiapkan.

b. Wawancara

Esterberg (dalam Sugiyono 2013:231) mendefinisikan wawancara adalah merupakan pertemuan dua orang untuk bertukar informasidan ide melalui tanya jawab, sehingga dapat dikonstruksikan makna dalam suatu topik tertentu. Wawancara digunakan sebagai teknik pengumpulan data apabila peneliti ingin melakukan studi pendahuluan untuk menemukan permasalahan yang harus diteliti, tetapi juga apabila peneliti ingin mengetahui hal-hal dari responden yang lebih mendalam.

c. Dokumentasi

Dokumen merupakan catatan peristiwa yang sudah berlalu. Dokumen biasa berbentuk tulisan gambar, atau karya-karya monumental dari seseorang. Hasil penelitian juga akan semakin kredibel apabila didukung oleh foto-foto atau atura-aturan yang telah ada.

Berdasarkan uraian di atas, dalam penelitian ini peneliti mengambil dokumentasi tentang peran UPT perpustakaan Universitas Muhammadiyah Matataram dalam menghadapi era new normal

\section{PEMBAHASAN}

Menurut kamus besar bahasa Indonesia (KBBI) peran mempunyai arti pemain sandiwara (film), tukang lawak pada permainan makyong, perangkat tingkah yang diharapkan dimiliki oleh orang yang berkedudukan di masyarakat.

Pengertian peran menurut Soerjono Soekanto (2002:243) yaitu:

"Peran merupakan aspek dinamis kedudukan (status), apabila seseorang melaksanakan hak dan kewajibannya sesuai dengan kedudukannya, maka ia menjalankan suatu peranan".

Sedangkan menurut Wiji Suwarno (2015:40-41) menjelaskan bahwa: 
"Istilah peran untuk sebuah perpustakaan adalah kedudukan, posisi dan tempat yang dimainkan apakah penting, strategis sangat menentukan, berpengaruh, atau hanya sebagai pelengkap dan lain sebagainya”.

Berdasarkan definisi diatas peneliti dapat menarik kesimpulan bahwa peran merupakan kedudukan atau posisi dalam melaksakan hak dan kewajiban sesuai dengan kedudukan karena peran yang dimainkan itu apakah penting, strategis, sangat menentukan, berpengaruh atau hanya sebagai pelengkap saja.

\section{Definisi Perpustakaan}

Perpustakaan (termasuk didalamnya pusat dokumentasi dan informasi) menurut Keputusan Menteri Pendayagunaan Aparatur Negara nomor 132/KEP/M.PAN/12/2002 adalah sebuah unit kerja yang memiliki sumberdaya manusia, ruang khusus dan koleksi bahan pustaka sekurang-kurangnya terdiri dari 1.000 judul dari berbagai disiplin ilmu yang sesuai dengan jenis perpustakaan yang bersangkutan dan dikelola menurut sistem tertentu. (Abdul Rahman Saleh dan Rita Komalasari, 2014:1.4)

Sedangkan pengertian perpustakaan menurut Basuki dalam Sumlati (2012:5), perpustakaan adalah sebuah ruangan,bagian sebuah gedung, atau gedung itu sendiri yang digunakan untuk menyimpan buku dan terbitan yang biasanya disimpan

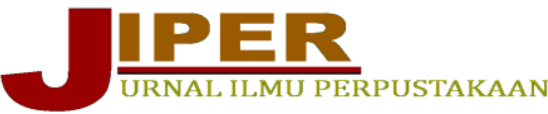

FISIP UMMAT | ISSN 2716-0432

Vol. 2, No. 2 November 2020, Hal. 88-103

menurut tata susunan tertentu untuk digunakan pembaca, bukan untuk dijual.

\section{Peran Perpustakaan}

Menurut Sulistyo Basuki (1991), setiap perpustakaan dapat mempertahankan eksistensinya apabila dapat menjalankan pernannya. Secara umum peran-peran yang dapat dilakukan adalah:

a. Sebagai pusat informasi

Perpustakaan merupakan salah satu tempat yang memiliki peranan penting dalam memberikan suatu iformasi. Hal ini dikarenakan sebuah peprustakaan pastinya mempunyai koleksi buku tidak hanya satu, bisa ratusan ribu bahkan berpuluh-puluh ribu. Yang didalamnya terdapat berbagai macam jenis buku, seperti karya umum, filsafat, ensiklopedi dan lain-lain. Tidak hanya buku, perpuatakaan sekarang juga dilengkapi dengan adanya koleksi majalah, koran ataupun artike yang dapat dijadikan sumber informasi dan juga ilmu.

b. Sebagai pusat inovasi

Perpustakaan sebagai tempat tersimpannya berbagai informasi yang dulu hanya sebagai tempat penyimpanan buku semata, kini juga sebagai tempat untuk tumbuhnnya ide-ide yang kreatif. Dari ide-ide kreatif itulah dapat tercipta suatu karya yang dapat bermanfaat bagi 
orang lain. Dan dari karya para pengguna perpustakaan inilah nantinya dapat pula muncul suatu wacana ataupun gagasan yang dapat dibaca dan digunakan oleh orang lain.

c. Sebagai pusat sumber belajar

Perpustakaan merupakan upaya untuk memelihara dan meningkatkan efisiensi dan efektivitas proses belajar mengajar. Perpustakaan yang terorganisasi secara baik dan sistematis, secara langsung atau pun tidak langsung dapat memberikan kemudahan bagi proses belajar mengajar di sekolah tempat perpustakaan tersebut berada. Hal ini terkait dengan bidang pendidikan dan dengan adanya perbaikan metode belajar mengajar yang dirasakan tidak bisa dipisahkan dari masalah penyediaan fasilitas dan sarana pendidikan

\section{HASIL DAN PEMBAHASAN}

1. Eksistensi Peran UPT Perpustakaan Universitas Muhammadiyah Matataram Dalam Menghadapi Era Pandemi Covid19.

Satu tempat yang juga ikut terdampak ialah perpustakaan. Perpustakaan jenis dan di mana pun itu, mungkin saat ini tidak lagi membuka pintunya untuk memberikan layanan, khususnya peminjaman dan pengembalian koleksi. Untuk perpustakaan perguruan tinggi, sedikit beruntung, karena beberapa koleksi perpustakaan dapat diakses secara via online, seperti ebooks dan ejournals. Bagaimana dengan perpustakaan-perpustakaan yang ada di sekolah. Tutupnya sekolah maka tutup pula perpustakaannya. Semakin lengkaplah penderitaan selama physical distancing yang dialami oleh guru-guru di sekolah. Terkhusus bagi para guru yang tidak dapat memanfaatkan media teknologi informasi saat ini.

Tidak mungkin rasanya bisa memenuhi dahaga para pencari ilmu, akan tetapi dengan situasi wabah corona saat ini, semua perpustakaan bergerak bersama saling berbagi setiap koleksi-koleksi yang dimilikinya. Perpustakaan Nasional RI dengan iPusnas dan e-resources nya, perpustakaan umum dan perguruan tinggi dengan repositorinya masing-masing telah menyediakan beragam ilmu pengetahuan bagi siapa saja yang menginginkannya, dan masih banyak lagi media-media online lainnya yang menghimpun ilmu pengetahuan. Maka dari itu, peran pustakawan ataupun pengelola perpustakaan sangat diharapkan di situasi saat ini, di antaranya yakni bagaimana masyarakat dapat diarahkan ke sumbersumber ilmu pengetahuan yang dapat mereka manfaatkan untuk mengerjakan tugas kuliahnya, menambah wawasan, 
membuat artikel jurnal atau buku, mengisi waktu luang, ataupun sebagai penyeimbang berita tentang Covid-19 yang mencemaskan yang hampir setiap saat diterima di smartphone masing-masing.

Perpustakaan tetaplah perpustakaan yang menjadi wadah atau lembaga yang senantiasa menerangi masyarakat dengan ilmu pengetahuan. Pandemi Covid-19 sepatutnya bukan menjadi tantangan berarti bagi perpustakaan yang mampu memanfaatkan sarana IT saat ini. Ketika orang-orang menjauhkan diri dengan orang lain (physical atau social distancing), perpustakaan sebaliknya, momentum ini dapat dijadikan sebagai usaha untuk lebih mendekatkan diri ke orang lain, dalam konteks UPT Perpustakaan Universitas Muhammadiyah Mataram yaitu ke seluruh sivitas akademika, ke seluruh anggota fakultas Universitas Muhammadiyah Mataram.

Menurut Sulistyo Basuki (1991), setiap perpustakaan dapat mempertahankan eksistensinya apabila dapat menjalankan pernannya. Secara umum peran-peran yang dapat dilakukan adalah: (1) Sebagai pusat informasi (2) Sebagai pusat inovasi (3) Sebagai pusat sumber belajar.

a. Sebagai pusat informasi

$$
\text { Menurut Yusuf, (1995 : 16) }
$$

Sumber informasi adalah wadah dari isi

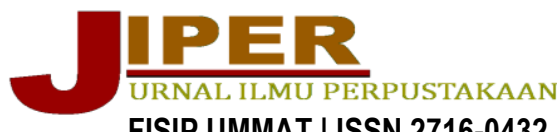

FISIP UMMAT | ISSN 2716-0432

Vol. 2, No. 2 November 2020, Hal. 88-103

tesebut, dan pusat sumber informasi adalah tempat terkumpulnya sumbersumber informasi atau wadah-wadah tadi. Kalau isi suatu buku adalah informasinya, maka disebut dengan sumber informasi adalah buku itu sendiri yang berfungsi sebagai penyimpanan atau penampungan informasi, sedangkan pusat sumber informasi bisa bermakna tempat terkumpulnya buku-buku atau sumber-sumber informasi buku atau sumber-sumber lainnya.

Sedangkan pendapat Hasugian, Jonner, (2009 : 134) Pusat informasi adalah suatu pusat yang bertugas memberikan informasi yang diolah dari sumber lain mengenai suatu bidang khusus atau bidang ilmu tertentu. Contoh pusat informasi pertanian, pusat informasi pariwisata dan sebagainya. Pusat sumber informasi perpustkaan hendaknya kita tafsirkan sebagai sumber informasi yang diolah dan mempunyai makna-makna dan informasi penting yang dibutuhkan pengguna untuk mencari beragam informasi.

Untuk mengetahui tentang peran perpustakaan sebagai tempat informasi, berdasarkan hasil wawancara dengan informan pertama bahwa;

Dalam melayani pemustaka agar selalu mendapatkan informasi, perpustakaan tidak hanya 
memanfaatkan koleksi tercetak saja tetapi juga memanfaatkan koleksi berbasis digital.

Berdasarkan hasil wawancara dengan informan kedua bahwa;

Selaku pustakawan menyatakan bahwa sebagai pusat informasi, perpustakaan selalu berusaha memberikan layanan yang baik kepada para pemustaka agar mendapatkan informasi yang diinginkan, oleh karena itu perpustakaan tidak hanya memanfaatkan koleksi tercetak saja tetapi juga memanfaatkan koleksi non cetak (digital).

Dari kedua informan yang diwawan carai, mereka memiliki pemahaman yang mengenai peran perpustakaan meski dengan dengan penjelasan yang berbeda-beda. kesimpulan bahwa UPT Perpustakaan Universitas Muhammadiyah Mataram tidak hanya memanfaatkan koleksi tercetak saja dalam memberikan informasi kepda para pemustaka tetapi juga memanfaatkan koleksi berbasis online.

b. Sebagai pusat inovasi

Berdasarkan hasil wawancara dengan informan pertama bahwa;

Untuk meningkatkan inovasi salah satu langkah yang dilakukan dengan bekerjasama dengan pihak fakultas/program studi guna meningkatkan sumber referensi belajar bagi mahasiswa, mengadakan webinar dengan bekerjasama dengan setiap program studi yang ada agar informasi yang didapat tidak hanya sebatas dari perpustakaan saja.

Berdasarkan hasil wawancara dengan informan kedua menayatakan bahwa;

Hal yang berbeda yaitu sebagai pusat inovasi, perpustakaan selalu berusaha menampilkan sesuatu yang bisa menggugah keinginan pemustaka seperti dengan menyediakan koleksi yang lebih bervariasi sehingga dengan mendapatkan informasi dari berbagai macam koleksi dapat menumbuhkan ide-ide kreatif.

Dari pendapat narasumber diatas dapat ditarik kesimpulan bahwa UPT Perpustakaan Universitas Muhammadiyah Mataram dengan mengadakan kerjasama dan menyediakan koleksi yang bervariasi dapat menumbuhkan ide-ide kreatif para pemustaka.

Upaya melakukan inovasi koleksi harus dipertimbangkan dan dilakukan pada kegiatan bidang pengembangan koleksi perpustakaan agar koleksi semakin menarik hati pemustaka. Bila hal ini dilakukan secara cermat dan selektif terhadap kebutuhannya diharapkan intensitas pemustaka berkunjung dan memanfaatkan koleksi akan semangkin meningkat. Ibarat menu yang disajikan di perpustakaan itu lebih 
sempurna mencukupi untuk seluruh pengguna yang hadir menikmati hidangan dengan menu yang oaling lengkap, menu-menu informasi yang paling mutakhir keluaran paling anyar. Informasi yang akan mengundang hasrat para pengguna untuk menikmati dan mengemas ulang informasi menjadi sesuatu informasi dan pengetahuan yang baru. berpeluang lebih besar pula untuk menghadirkan pemustaka dari berbagai lapisan masyarakat informasi.

Maka tidak heran ketika banyak bermunculan pusat-pusat informasi yang menyediakan menu-menu informasi untuk menarik masyarakat yang sangat membutuhkan variasi-variasi bahan informasi, demi melengkapi referensi yang dibutuhkan saat mengkopilasi komposisi menu-menu informasi yang akan diciptakan. Menu-mennu temuan baru yang akan melengkapi tebaran informasi-informasi di dunia konvensional maupun informasi di dunia maya. Sehingga diharapkan munculnya pusat-pusat informasi yang menyediakan menu-menu informasi yang menarik di tengah-tengah masyarakat dapat melepas borgol yang membelenggu, melepas tali yang mengikat semangat baca masyarakat agar bergairah kembali dalam

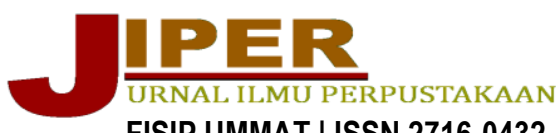

FISIP UMMAT | ISSN 2716-0432

Vol. 2, No. 2 November 2020, Hal. 88-103

mambacanya.

c. Sebagai pusat sumber belajar

Berdasarkan hasil wawancara dengan informan pertama bahwa;

Mengenai kerjasama yang dilakukan dengan program studi/fakultas guna memenuhi kebutuhan informasi yang dibutuhkan pemustaka, maka dengan cara tersebut para pemustaka menjadi lebih memanfaatkan perpustakaan sebagai tempat belajar.

Berdasarkan hasil wawancara dengan informan pertama bahwa;

Selain dengan menyediakan koleksi yang dibutuhkan pemustaka juga dengan menyediakan berbagai macam fasilitas yang ada di perpustakaan yang dapat menunjang kegiatan belajar mengajar di perpustakaan.

Dari pendapat diatas dapat ditarik kesimpulan bahwa UPT Perpustakaan Universitas Muhammadiyah Mataram selain dengan pemenuhan kebutuhan informasi yang dibutuhkan oleh pemustaka sebagai sumber belajar juga dengan menyediakan fasilitas yang dapat menunjang kegiatan tersebut.

Perpustakaan merupakan salah satu penunjang dalam meningkatkan sumber belajar yang sekaligus sebagai wadah dari berbagai disipilin ilmu pengetahuan yang juga menunjang atau sebagai sarana dalam mencerdaskan 
kehidupan bangsa khususnya dibidang pendidikan.

Perpustakaan adalah suatu unit kerja dari suatu badan atau lembaga tertentu yang mengelola bahan-bahan pustaka, baik berupa buku-buku maupun bukan berupa buku (non book material) yang diatur secara sistematis menurut aturan tertentu sehingga dapat digunakan sebagai sumber informasi oleh setiap pemakainya. Jadi, perpustakaan adalah suatu unit kerja dari suatu lembaga yang berisi koleksi buku sebagai penunjang dalam meningkatkan sumber belajar yang diatur untuk dibaca, dipelajari, dan dijadikan bahan rujukan.

Penyelenggaraan perpustakaan sebagai sumber belajar merupakan suatu keharusan dan amat penting dalam pendidikan (UU No. 2/1989, pasal 35). Suatu lembaga pendidikan tidak mungkin dapat terselenggara dengan baik jika para guru dan para siswa tidak didukung oleh sumber belajar yang diperlukan untuk penyelenggaraan kegiatan belajar mengajar.

Smith dkk dalam buku ensiklopedianya yang berjudul "EDUCATOR'S ENCYCLOPEDIA" menyatakan "School Library is a Center for Learning", yang artinya perpustakaan itu merupakan sumber belajar. Memang ditinjau secara umum, perpustakaan itu sebagai pusat belajar sebab kegiatan yang paling tampak pada setiap kunjungan mahasiswa adalah belajar, baik belajar masalah-masalah yang berhubungan langsung dengan mata kuliah yang diberikan di ruang kuliah, maupun buku-buku lain yang tidak ada hubungannya dengan mata kuliah. Akan tetapi apabila ditinjau dari sudut tujuan mahasiswa mengunjungi perpustakaan, maka ada yang tujuannya untuk belajar, ada yang tujuannya untuk berlatih menelusuri buku-buku perpustakaan, ada yang tujuannya untuk memperoleh informasi, bahkan mungkin ada juga mahasiswa yang mengunjungi perpustakaan dengan tujuan hanya sekedar untuk mengisi waktu senggangnya atau sifatnya rekreatif.

Bila diperhatikan secara jenih, maka perpustakaan sesungguhnya memberikan peranan terhadap pelaksanaan pendidikan antara lain :

1) Perpustakaan merupakan sumber ilmu pengetahuan dan pusat kegiatan belajar.

2) Perpustakaan merupakan sumber ideide baru yang dapat mendorong kemauan para siswa untuk dapat berpikir secara rasional dan kritis 
serta memberikan petunjuk untuk mencipta.

3) Perpustakaan akan memberikan jawaban yang cukup memuaskan bagi para siswa, sebagai tuntutan rasa keingintahuan terhadap sesuatu, benar-benar telah terbangun.

4) Kumpulan bahan pustaka (koleksi) di perpustakaan memberikan kesempatan membaca bagi para siswa yang mempunyai waktu dan kemampuan yang beraneka ragam.

5) Perpustakaan memberikan kesempatan kepada para siswa untuk mempelajari cara mempergunakan perpustakaan yang efisien dan efektif.

6) Perpustakaan akan membantu para siswa dalam meningkatkan dalam kemampuan membaca dan memperluas perbendaharaan bahasa.

7) Perpustakaan dapat menimbulkan cinta membaca, sehingga dapat mengarahkan selera dan apresiasi siswa dalam pemilihan bacaan.

8) Perpustakaan memberikan kepuasan akan pengetahuan di luar kelas.

9) Perpustakaan merupakan pusat rekreasi yang dapat memberikan hiburan yang sehat.

10) Perpustakaan memberikan kesempatan kepada para siswa dan guru untuk mengadakan penelitian.

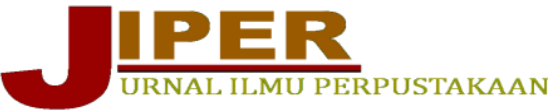

FISIP UMMAT | ISSN 2716-0432

Vol. 2, No. 2 November 2020, Hal. 88-103

11) Perpustakaan merupakan batu loncatan bagi para siswa untuk melanjutkan kebiasaan hidup membaca di sekolah yang lebih tinggi.

12) Kegairahan/minat baca siswa yang telah dikembangkan melalui perpustakaan sangat berpengaruh positif terhadap prestasi belajarnya.

13) Bila minat membaca sudah tumbuh dan berkembang pada diri siswa, maka perpustakaan juga dapat mengurangi jajan anak, yang ini biasanya dapat berpengaruh negatif terhadap kesehatan anak.

14) Bahkan perpustakaan juga bagi anak-anak dapat menjauhkan diri dari tindakan kenakalan, yang bisa menimbulkan suasana kurang sehat dalam hubungan berteman diantara mereka.

Perpustakaan sebagai lembaga penyedia ilmu pengetahuan dan informasi mempunyai peranan yang signifikan terhadap lembaga induk serta masyarakat penggunanya. Demikian halnya di dalam lingkungan perguruan tinggi. Perpustakaan merupakan pusat sumber ilmu pengetahuan dan informasi yang berada di perguruan tinggi, baik tingkat jurusan sampai dengan tingkat Universitas. Perpustakaan perguruan tinggi harus dapat memainkan peran, 
khususnya dalam membantu mahasiswa untuk mencapai tujuan pendidikan di perguruan tingggi. Untuk tujuan tersebut, perpustakaan perguruan tinggi perlu merealisasikan misi dan kebijakannya dalam memajukan civitas akademika dengan mempersiapkan tenaga pustakawan yang memadai, koleksi yang berkualitas serta serangkaian aktifitas layanan yang mendukung suasana pembelajaran yang menarik.

Dalam menjalankan peran menghadapi era new normal ini, UPT Peprustakaan Muhammadiyah Mataram melakukan penerapan physical distancing, social distancing dan protokol kesehatan guna dapat mencegah/menghentikan penularan virus Corona (Covid-19). Berikut penjelasan dari para narasumber mengenai penerapan physical distancing, social distancing dan protokol kesehatan:

1) Physical Distancing

Berdasarkan hasil wawancara dengan informan pertama bahwa;

Dalam penerapan physical distancing ini, UPT Perpustakaan Universitas Muhammadiyah Mataram menerapkan pembatasan jumlah pengunjung dikarenakan kapasitas ruang baca yang minim sehingga harus ada pembatasan, dalam menjalankan layanan sirkulasi dengan memanfaakan media sosial.
Berdasarkan hasil wawancara dengan informan pertama bahwa;

Penerapan physical distancing dengan mewajibkan pemustaka menggunakan masker, menggunakan handsanitizer, dan menjaga jarak ketika berada didalam perpustakaan, dianjurkan koleksi dipinjam hal ini dilakukan untuk menghindari kerumunan.

Dari pendapat narasumber diatas dapat ditarik kesimpulan bahwa UPT Perpustakaan

Universitas Muhammadiyah Mataram menerapkan physical distancing dengan cara melakukan pembatasan jumlah pengunjung, memanfaatkan media sosial untuk menjalankan layanan sirkulasi, mewajibkan penggunaan masker, menyediakan hand sanitizer dan melakukan pembatasan jarak ketika berada didalam perpustakaan.

2) Social Distancing

Berdasarkan hasil wawancara dengan informan pertama bahwa;

Menerapkan social distancing dengan cara pengaturan jarak duduk pada ruang tunggu, meja sirkulasi, pelayanan berbasis online dengan memanfaatkan media sosial.

Berdasarkan hasil wawancara dengan informan kedua bahwa;

Mengenai penyesuaian kursi pengunjung dengan memberikan jarak duduk minimal 1 kusri, pemustaka tidak diperkenankan berkerumunan ketika melakukan pemilihan buku pada rak 
buku, dan juga melakukan pembatasan layanan sirkulasi secara langsung dan lebih menggunakan layanan sirkulasi secara online dengan memanfaatkan media sosial.

Dari penjelasan narasumber diatas maka dapat ditarik kesimpulan bahwa penerapan social distancing di UPT Perpustakaan

Universitas

Muhammadiyah Mataram melakukan aktivitas dengan cara melakukan pembatasan baik itu jarak duduk pengunjung, jarak ketika pemustaka melakukan pencarian bahan pustaka dan pembatasan layanan sirkulasi secara langsung dan lebih menerapkan layanan sirkulasi secara online.

3) Penerapan Protokol Kesehatan

Protokol kesehatan yang diterapkan di UPT Perpustakaan Universitas Muhammadiyah Mataram ini sesuai dengan protokol kesehatan keputusan dari Mentri Kesehatan RI,

Berdasarkan hasil wawancara dengan informan pertama bahwa;

Protokol kesehatan yang diterapkan di UPT Perpustakaan Universitas Muhammadiyah Mataram ini sesuai dengan keputusan dari Mentri Kesehatan RI tetapi dari 17 point yang dituliskan ada beberapa point yang sudah tidak dilakukan lagi untuk sekarang ini seperti pengaturan kerja dari rumah, memberikan asupan nutrisi yang diberikan oleh tempat kerja dan meniadakan shift 3 bagi pekerja.

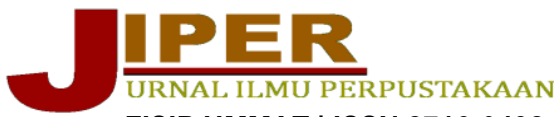

FISIP UMMAT | ISSN 2716-0432

Vol. 2, No. 2 November 2020, Hal. 88-103

Berdasarkan hasil wawancara

dengan informan kedua bahwa;

Penerapan protokol kesehatan yang diterapkan di UPT Perpustakaan Universitas Muhammadiyah Mataram yaitu seperti membagikan masker bagi pengunjung yang tidak membawa masker, melakukan webinar tentang bagaimana layanan peprustakaan di era new normal ini, melakukan pengecekan suhu tubuh pada pintu masuk, melakukan social distancing dan physical distancing ketika berada di area perpustakaan.

Adapun isi dari protokol kesehatan keputusan dari mentri kesehatan nomor HK.01.07/MENKES/328/2020, antara lain:

a. Perusahaan wajib membentuk tim penanganan Covid-19 di tempat kerja yang terdiri dari pimpinan, bagian kepegawaian, bagian $\mathrm{K} 3$ dan petugas kesehatan yang diperkuat dengan surat keputusan dari pimpinan tempat kerja.

b. Pimpinan atau pemberi kerja memberikan kebijakan dan prosedur untuk pekerja melaporkan setiap kasus dicurigai Covid-19 (gejala demam atau batuk/pilek/nyeri tenggorokan/sesak napas) untuk dilakukan pemantauan oleh petugas kesehatan.

c. Tidak memperlakukan kasus positif sebagai suatu stigma. 
d. Pengaturan bekerja dari rumah (work from home) dengan menentukan pekerja esensial yang perlu tetap bekerja/datang ke tempat kerja dan pekerja yang dapat melakukan pekerjaan dari rumah.

e. Di pintu masuk tempat kerja lakukan pengukuran suhu dengan menggunakan thermogun, dan Assessment Risiko Covid-19 untuk memastikan pekerja yang akan masuk kerja dalam kondisi tidak terjangkit Covid-19.

f. Pengaturan waktu kerja tidak terlalu panjang (lembur) yang akan mengakibatkan pekerja kekurangan waktu untuk beristirahat yang dapat menyebabkan penurunan sistem kekebalan/imunitas tubuh.

g. Jika memungkinkan tiadakan shift 3 (waktu kerja yang dimulai pada malam hingga pagi hari). Bagi pekerja shift 3 atur agar yang bekerja, terutama pekerja yang berusia kurang dari usia 50 tahun.

h. Mewajibkan pekerja menggunakan masker sejak perjalanan dari/ke rumah, dan selama ditempat kerja.

i. Mengatur asupan nutisi makanan yang diberikna oleh tempat kerja, pilih buah-buahan yang banyak mengandung vitamin $\mathrm{C}$ seperti jeruk, jambu dan sebagainya untuk membantu mempertahankan daya tahan tubuh, jika memungkinkan perkerja dapat diberikan suplemen vitamin $\mathrm{C}$.

j. Memastikan seluruh area kerja bersih dan higienis dengan melakukan pembersihan secara berkala dengan menggunakan pembersih dan desinfektan yang sesuai (setiap 4 jam sekali). Terutama pegangan pintu dan tanggga, tombol lift, peralatan kantor ang digunakan bersama, area dan fasilitas umum lainnya.

k. Menjaga kualitas udara tempat kerja dengan mengoptimalkan sirkulasi udara dan sinar mataharai masuk ruangan kerja, pembersihan filter AC.

1. Menyediakan hand sanitizer dengan konsentrasi alkohol minimal $70 \%$ di tempat-tempat yang diperlukan (seperti pintu masuk, ruangan meeting, pintu lift dan lain-lain).

m. Menyediakan sarana cuci tangan (sabun dan air mengalir). Kemudian memberikan petunjuk lokasi sarana cuci tangan. Lalu memasang poster edukasi cara mencuci tangan yang benar.

n. Physical distancing dalan aktivitas kerja. Pengaturan jarak pekerja minimal 1 meter pada setiap aktivitas 
kerja meja

Vol. 2, No. 2 November 2020, Hal. 88-103

kerja/workstation, pengaturan kursi saat di kantin dan lain-lain).

o. Mengampanyekan gerakan masyarakat hidup sehat (Germas) melalui pola hidup sehat dan perilaku hidup bersih dan sehat (PHBS) di tempat kerja seperti makanan seimbang dan olahraga teratur.

p. Cuci tangan pakai sabun (CTPS) mendorong pekerja mencuci tangan saat tiba di tempat kerja, sebelum makan, setelah kontak dengan pelanggan/pertemuan dengan orang lain, setelah dari kamar mandi, setelah memegang benda yang kemungkinan terkontaminasi.

q. Hindari penggunaan alat pribadi secara bersama seperti alat shalat, alat makan dan lain-lain.

Dari penjelasan diatas dapat ditarik kesimpulan bahwa protokol kesehatan yang diterapkan oleh pihak UPT Perpustakaan Universitas Muhammadiyah Mataram sesuai dengan keputusan Mentri Kesehatan RI tetapi ada beberapa point yang sudah tidak diterapkan.

\section{E. KESIMPULAN DAN SARAN}

\section{Kesimpulan}

Berdasarkan hasil penelitian tentang Eksistensi Peran UPT Perpustakaan Universitas Muhammadiyah Matataram Dalam Menghadapi Era Pandemi Covid-19 yang telah dilakukan, maka dapat disimpulkan sebagai berikut, , Sebagai pusat sumber belajar:

a. Sebagai pusat informasi, Ketersediaan fasilitas penunjang pembelajaran di UPT Perpustakaan UMMAT masih belum cukup untuk memenuhi seluruh harapan dari pemusta, UPT Perpustakaan Muhammadiyah Mataram telah menyediakan fasilitas ruangan baca, layanan internet, web site, koleksi digital, dll. Sehingga kebutuhan informasi pemustaka bisa terlayani dengan baik.

b. Sebagai pusat inovasi, Penyediaan koleksi yang berbasis WEB, telah dilakukan namun kami masih memiliki kendala dalam kondisi pandemi saat ini, dikarenakan perangkat yang dimiliki oleh pemustaka saat ini masih perlu di tingkatkan kualitas sehingga lebih cocok dengan kondisi saat ini.

c. Sebagai pusat sumber belajar, UPT Perpustakaan Muhammadiyah Mataram telah menerapkan standar protokoler covid-19 secara ketat dengan cara 
menggunakan mengatur jarak,

menggunakan masker, serta

handsanitizer untuk menghidari penular covid-19

\section{Saran}

Berdasarkan kesimpulan diatas, maka saran dari peneliti sebagai berikut:

a. UPT Perpustakaan UMMAT diharapkan dapat memperbaiki atau meningkatakan fasilitas-fasilitas perpustakaan dalam menunjang kegiatan pelayanan disaat pandemi covid-19.

b. Perlu dibuat aturan yang lebih adaptif dengan kondisi covid-19, agar penyebaran covid-19 bisa dikendalikan

c. Bagi pegawai dan staf UPT Perpustakaan Universitas

Muhammadiyah Mataram bisa menjadi mitra pemerintah dalam mengendalikan penyebaran covid-19 saat ini.

\section{DAFTAR RUJUKAN}

Hasugian, Jonner. 2009. Dasar-Dasar Ilmu Perpustakaan Dan Informasi. Medan : USU Press.

Hartina, Sri. 2018. Metode Penelitian Perpustakaan. Tanggerang Selatan: Universitas Terbuka.

Library UMMAT. "Koleksi umum.” lib.ummat.ac.id. UPT Perpustakaan Universitas Muhammadiyah Mataram http://lib.ummat.ac.id/koleksi-umum/

NS, Sutarno. 2006. Manajemen Perpustakaan: Suatu Pendekatan Praktek. Jakarta: Sagung Seto.

Rahayuningsih, F. 2007. Pengolahan Perpustakaan. Yogyakarta: Graha Ilmu.

Republik Indonesia. 1990.Peraturan

Pemerintah Nomor 30 Tahun 1990. Jakarta: Sekretaris Negara.

Republik Indonesia. 2007. Undang-Undang Republik Indonesia Nomor 43 Tahun 2007 Tentang Perpustakaan. Jakarta: Sekretaris Negara.

Republik Indonesia. 1989. Undang-Undang Republik Indonesia Nomor 2 Tahun 1989 Tentang Sistem Pendidikan Nasional. Jakarta: Sekretaris Negara.

Saleh, Abdul Rahman. 2009. Pengantar Kepustakaan. Jakarta : Sagung Seto Soeatminah. 1992. Perpustakaan Kepustakawanan dan Pustakawan. Jakarta : Kanisius

Sujatna. 2016. Promosi perpustakaan. Jakarta: Mahara publishing.

Sujarweni, V. Wiratna. 2014. Metodologi Penelitian. Yogyakarta: Pustaka Baru Press 
Sutarno. 2006. Perpustakaan dan Masyarakat. Jakarta: IKAPI

Trimo, Soejono. 1992. Pedoman Pelaksanaan Perpustakaan. Bandung : Remaja Rosdakarya

Yusuf, Pawit M. 1995. Pedoman Praktis Mencari Informasi. Bandung: Remaja Rosdakarya.

\section{SUMBER ONLINE:}

http://perpustakaan.uinalauddin.ac.id/perpustakaan-di-tengahpandemi-covid-19/Akses, tanggal 10 november 2020 pkl. 16.31 wita.

Chromeextension://ohfgljdgelakfkefopgklcoh adegdpjf/file:///C:/Users/ASUSTECH/ Downloads/15199-37079-1PB.pdf/Akses tanggal 10 november 2020 pkl. 16.31 wita.

http://abdaumuhammad.blogspot.com/2013/0 6/perpustakaan-sebagai-pusatsumber.html/ Akses tanggal 10 november 2020 pkl. 17.12 wita. 